\title{
Diversification, Industry Concentration, and Bank Margins: Empirical Evidence from an Emerging South Asian Economy
}

\author{
Bilal SARWAR ${ }^{1}$, Noor MUHAMMAD ${ }^{2}$, Nadeem Uz ZAMAN ${ }^{3}$ \\ Received: May 09, 2020 Revised: May 24, 2020 Accepted: June 07, 2020
}

\begin{abstract}
The study aims to empirically examine the determinants of bank margins from Pakistan, an emerging South Asian economy. To elucidate the importance of the Pakistani banking sector, secondary data has been used, which was extracted from the annual accounts of twentyfour Pakistani scheduled commercial banks (20 conventional, four full-fledged Islamic) over a sample period of 2006 to 2017 . The factors identified in the dealership model and the subsequent empirical developments in the dealership model categorized as bank-specific, diversification, regulatory, and industry concentration are analyzed by applying the most-common linear dynamic panel-data estimator, the Generalized Method of Moments (GMM) estimator, developed by Arellano and Bond (1991). The findings reveal that, among the bank-specific variables, funding cost, credit risk, managerial efficiency, market share, and operating cost are significant predictors of bank margins. For diversification variables employed in the study, both variables including net non-interest income and asset diversity are as well significant predictors of bank margins. It is also found that the market concentration variable proxied by the Herfindahl-Hirschman Index (HHI) is significantly predicting bank margins. Subsequently, one of the regulatory variables, the opportunity cost of holding reserves, and one bank-specific variable, the degree of risk aversion, are insignificant in the model.
\end{abstract}

Keywords: Dealership Model, Diversification, Generalized Method of Moments, Scheduled Commercial Banks, Pakistan

JEL Classification Code: C33, C51, G21

\section{Introduction}

In conventional financial systems, commercial institutions, like banks provide financial intermediation

${ }^{1}$ First Author and Corresponding Author. Ph.D. Scholar, Department of Management Sciences, Faculty of Management Sciences, Balochistan University of Information Technology Engineering \& Management Sciences, Pakistan [Postal Address: House \# 6-5/5 Sheikhan Street Toghi Road, Quetta, Balochistan, 87200, Pakistan] Email: bilal.buitems@yahoo.com

${ }^{2}$ Associate Professor, Department of Management Sciences, Faculty of Management Sciences

Balochistan University of Information Technology Engineering \& Management Sciences, Pakistan.

Email: noor.muhammad@buitms.edu.pk

${ }^{3}$ Assistant Professor, Department of Management Sciences, Faculty of Management Sciences

Balochistan University of Information Technology Engineering \& Management Sciences, Pakistan.

Email: nadeem.zaman@buitms.edu.pk

(c) Copyright: The Author(s)

This is an Open Access article distributed under the terms of the Creative Commons Attribution Non-Commercial License (http://Creativecommons.org/licenses/by-nc/4.0/) which permits unrestricted noncommercial use, distribution, and reproduction in any medium, provided the original work is properly cited. in an economic system by directing financial assets from excessive economic sectors to trade and industrial sectors that are experiencing scarcity. Through this, they accelerate capital formation and savings in the economic system.

The banking sector is considered to have a major portion of the share in the overall financial sector of economies of the world, including banks, insurance companies, and other financial institutions. The Pakistani banking industry possesses some unique characteristics due to a dual banking system in place. This is due to the presence of traditional conventional banks working side-by-side with pure Islamic banks with the inception of Meezan Bank Limited since 2002. Due to intense rivalry in the banking industry and regulatory requirements laid out by the State Bank of Pakistan (SBP), several conventional banks are operating with Islamic banking windows to battle for a greater market share to exercise more market power enabling them to earn greater net income.

Net Interest Margin (NIM) is usually termed to be a key indicator of the bank's level of efficiency in terms of their fundamental role of financial intermediation. Due to the dual 
banking system in Pakistan, the present study used the term bank margins instead of NIM because Islamic banks, which are a part of the sample banks, work on their fundamental principle of interest-free banking. Conventional banks charge and pay a fixed rate of interest on extended loans and deposits, respectively, whereas Islamic banks work on a profit-andloss sharing basis (Kabir, Worthington, \& Gupta, 2015).

In their pioneering work of the US banking system, Ho and Saunders (1981) set the stage for contemporary theoretical and empirical research of banks' NIM widely known as the dealership model. The authors observed that extensive research has been undertaken to explain the factors affecting commercial banks' NIM in the US banking industry, the banking sector of Australia, European and Asian banks. Lin, Chung, Hsieh, and Wu (2012) emphasized that studies in NIM require more concentration on the Asian context as there is plenty of scope for studies on NIM in South Asian countries, for example, Afghanistan, Nepal, Bhutan, and the Maldives.

Current studies in South Asia include the empirical works by Kannan, Narain, and Ghosh (2001) and Barik and Raje (2019) for India, Chowdhury, Siddiqua, and Chowdhury (2016) in Bangladesh, Kumari (2014) for Srilanka and the work of Ghasemi and Rostami (2015) in Iran. Single-country studies in Pakistan begin from the pioneering empirical work by Khawaja and Ud Din (2007) followed by the study by Khan and Khan (2010), Hussain (2014), and Khan and Jalil (2020). Cross-country studies include the empirical work by Doliente (2005) and Islam and Nishiyama (2016) for Southeast Asian countries, the empirical work by Lin et al. (2012) for Asian countries.

In Pakistan, the pioneering empirical work by Khawaja and Ud Din (2007) concludes that the market share, nonperforming loans, liquidity, administrative cost, interestinsensitivity of deposits, and the real interest rate is significantly predicting interest spread positively while the real GDP has a negative association with interest spread. Hussain (2014) applied the Estimated Generalized Least Square (EGLS) on secondary data from 2001-2010 and found that operating cost, bank soundness, market share, diversification, bank size, concentration, depreciation, industrial growth, and development of the stock market are significant predictors of net interest margins. Khan and Jalil (2020) found that the Lerner index, operating costs, interest rate risk, credit risk, size, the T-bill rate, inflation, profit tax, national savings, and money supply are predicting NIM. Pakistan's banking sector leads the country's financial sector with the largest share of 95 percent (Husain, 2006). Bank margins indicate a bank's level of efficiency during financial intermediation; the data reveals that the average margins of banks in Pakistan are continuously declining; the average bank margins declined from 3.5 percent in 2014 to 2.65 percent in 2017. These facts indicate that the decreasing levels of bank margins are a complex issue presently faced by Pakistan's economy.

Therefore, this study aims to empirically analyze the bankspecific, regulatory, diversification, and industry-specific determinants of bank margins in Pakistan, including some novel factors such as funding cost, capital adequacy ratio, and asset diversity categorized as bank-specific, regulatory, and diversification variables, respectively. The empirical model is estimated by applying the linear dynamic panel-data GMM estimator developed by Arellano and Bond (1991).

This empirical research is making several significant contributions to the existing literature on bank margins. The main contribution of this study to the literature is related to the use of funding cost as a bank-specific variable, the capital adequacy ratio as a regulatory variable, and asset diversity as a diversification variable for Pakistan's banking sector for the first time. The findings indicate that funding cost, capital adequacy ratio, and asset diversity are significant predictors of bank margins. Second, the research makes use of a unique balanced panel annual dataset from 20062017 to present fresh evidence on the factors predicting bank margins of scheduled commercial banks working in Pakistan, an important emerging Asian market. Third, this study applied the Arellano-Bond (AB) linear dynamic panel-data GMM estimator for the first time in the Pakistani context to empirically examine simultaneously the bankspecific, regulatory, diversification, and industry-specific determinants of bank margins. It is different from the work of Khawaja and Ud Din (2007), who used the Feasible Generalized Least Square (FGLS) estimation technique to analyze their empirical model and the study conducted by Khan and Khan (2010), who applied the Fixed Effect (FE) estimator in their empirical work. Our study also contrasts with Hussain (2014), who used the EGLS estimation technique to analyze their empirical model, and Khan and Jalil (2020), who analyzed unbalanced quarterly panel data using a two-step system GMM.

The study is structured in the following manner: Section 2 focuses on the review of the literature; Section 3 provides the data, empirical variables, hypotheses, and the methodology adopted; Section 4 presents the empirical results and discussion of the study, followed by conclusions and recommendations in Section 5.

\section{Literature Review}

Ho and Saunders (1981) are considered to be the pioneers for their theoretical attempt to determine the factors explaining NIM for US banks. The dealership model takes banks as risk-averse dealers of a country's financial market; additionally, they concluded that transaction size, degree of risk aversion, the market structure, and interest rate risk are predicting banks' NIM. Several researchers have extended 
the renowned dealership model in their empirical and theoretical works.

McShane and Sharpe (1985) modified the original dealership model with the addition of product portfolio, cash, short-term money market assets, and shareholders funds into the balance of a bank in their extended model for the commercial banks of Australia. The model was applied to eight Australian banks and the results demonstrate a positive association of average transaction size, risk aversion, and volatility in the interest rate with bank margins. Allen (1988) extended it in a single product dealership model by applying the methodology of Ho and Stoll (1983) and concluded that, through the use of portfolio diversification, the spread can be reduced. Angbazo (1997) in his empirical work for US commercial banks adjusted the dealership model with the inclusion of variables like the default risk, the interest rate risk, and their interaction by analyzing secondary data for a sample period of 1989-1993. Their work aimed at testing the hypothesis that banks exposed to high risk-based loans and greater risk exposure to rates of interest will set the rates for extending loans and accepting deposits to attain higher NIMs.

Maudos and De Guevara (2004) incorporated banks' operating cost and degree of competition apart from all the variables of the dealership model and examined the data for the European banking sector and concluded that market structure and operating costs are significantly determining the bank margin. It was concluded that banks with high operating costs have higher margins for the intermediation process, taking market power and other risk factors into consideration. Specifically, the Lerner Index was proxied for the competition, which was found positively related to the bank margins, whereas interest rates, cost structure, and the credit risk were negatively related to bank margins.

A multi-product framework was devised by Carbo Valverde and Rodríguez Fernández (2007), which reflected more sufficiently the diversification of banks' output. Their extended model was an addition to the empirical work of Allen (1988) as they employed traditional assets (loans) as well as non-traditional assets in their work. They stated that banks that specialize in loans shrink the financial intermediation cost by providing fewer margins due to information advantages. Due to non-traditional activities by the banks like non-loan assets and fee income activities, the NIM increases implying that banks, which are diversified, have higher margins compared to their specialized counterparts. They incorporated prices for loans and deposits other than non-traditional activities in their multi-output model to explore the factors affecting bank margins for seven European countries. They concluded that market power is strengthened as output is diversified, and there is a higher spread in bank-based systems compared to market-based systems.

Williams (2007) carried out empirical research in Australia from 1989 to 2001 using forty-three banks to determine the factors affecting bank margins. The empirical results suggest that management quality, implied payments, and operating costs were significantly determining bank margins, as net interest margin increases due to market power. The Ho and Saunders dealership model was extended and tested by Maudos and Solís (2009) in the Mexican banking sector. They modeled specialization, diversification, and operating costs at the same time as a determinant of bank margin in Mexico and the results indicate that market power and average operating cost largely explain high margins for banks, while there is a low economic impact of non-interest income on bank net interest margins. Lin et al. (2012) extended the empirical work of Angbazo (1997) for US commercial banks who adjusted the dealership model with the inclusion of variables like the interest rate and credit risk as well as their interaction by including bank diversification variables in their empirical work for Asian countries and the results reveal that diversification variables were significantly predicting NIM in these countries.

Lee and Isa (2017) empirically analyzed the variables affecting bank margins for Malaysia, including funding cost as a variable for the first time. Their empirical work in the dual banking system of Malaysia found that among the spread variables employed in the study including market share, operating cost, the degree of risk aversion, and credit risk market share were positively related to bank margins whereas operational efficiency had a negative relationship with bank margins. Funding cost and implicit interest payment were positively associated while the opportunity cost for holding reserve was found to be insignificant with bank margin.

\section{Data and Methods}

\subsection{Data}

The secondary data has been extracted from the annual accounts of scheduled banks incorporated in Pakistan from the publications of State Bank of Pakistan (SBP). During the data cleaning process and selecting banks that have complete data for the sample study period for making a balanced panel, twenty-four banks were chosen for the present study fulfilling the inclusion criteria. The description of variables, the mean and standard deviation of every variable of the study are presented in Table 1.

\subsection{Methods}

\subsubsection{Model Specification}

To empirically test the relationship between bankspecific, regulatory, diversification, and industry-specific variables with bank margin in Pakistan, the following dynamic panel model is formulated: 
Table 1: Description of Variables

\begin{tabular}{|c|c|c|c|c|}
\hline Variables & Acronym & Measurement & Mean & S.D. \\
\hline Bank Margin & BM & $\begin{array}{l}\text { The ratio of difference of interest income and interest expenses } \\
\text { to total assets (conventional) } \\
\text { The ratio of difference of markup earned and markup expensed } \\
\text { to total assets (Islamic) }\end{array}$ & 0.032 & 0.013 \\
\hline \multicolumn{5}{|l|}{ Bank-specific variables } \\
\hline Market Share & MS & $\begin{array}{l}\text { Total loans of a bank divided by total loans of all banks in the } \\
\text { sample }\end{array}$ & 0.042 & 0.044 \\
\hline Operating cost & OC & The ratio of operational costs to total assets & 0.031 & 0.019 \\
\hline Managerial Efficiency & ME & The ratio of operating expenses to gross income & 0.454 & 0.617 \\
\hline Credit Risk & CR & The ratio of non-performing loans to total loans & 0.129 & 0.146 \\
\hline Degree of Risk aversion & DRA & Total equity divided by total assets of a bank & 0.236 & 0.985 \\
\hline Funding cost & $\mathrm{FC}$ & $\begin{array}{l}\text { The ratio of interest on deposits to total deposits for } \\
\text { conventional banks } \\
\text { The ratio of return on deposits to total deposits for Islamic banks }\end{array}$ & 0.071 & 0.042 \\
\hline \multicolumn{5}{|l|}{ Regulatory variables } \\
\hline Capital Adequacy Ratio & CAR & $\begin{array}{l}\text { The ratio of Tier } 1 \text { capital plus Tier } 2 \text { capital divided by total } \\
\text { risk-weighted assets }\end{array}$ & 0.188 & 0.131 \\
\hline $\begin{array}{l}\text { The opportunity cost of } \\
\text { keeping reserves }\end{array}$ & OCR & The ratio of liquid reserves at SBP to total assets & 0.094 & 0.043 \\
\hline \multicolumn{5}{|l|}{ Diversification variables } \\
\hline Net non-interest income & NNII & $\begin{array}{l}\text { Net non-interest income divided by total assets (conventional) } \\
\text { Net non-markup income divided by total assets (Islamic) }\end{array}$ & 0.018 & 0.019 \\
\hline Asset diversity & $A D$ & $1-|2 x-1|$, where $x$ denotes total loans to total assets & 0.502 & 0.177 \\
\hline \multicolumn{5}{|l|}{ Industry-specific variable } \\
\hline Market Structure & $\mathrm{HHI}$ & Sum of Square of the market share of each bank & 0.318 & 0.279 \\
\hline
\end{tabular}

$$
\begin{aligned}
B M_{i t}= & \alpha_{0}+\alpha_{1} B M_{i t-1}+\beta_{1} M S i t+\beta_{2} O C_{i t}+\beta_{3} M E_{i t}+ \\
& \beta_{4} C R_{i t}+\beta_{5} D R A_{i t}+\beta_{6} F C_{i t}+\beta_{7} C A R_{i t}+\beta_{8} O C R_{i t}+ \\
& \beta_{9} D I V_{i t}+\beta_{10} H H I_{t}+\mu_{i}+\varepsilon_{i t}
\end{aligned}
$$

Where $B M_{i t}$ denotes the bank margin for bank ' $i$ ' in year ' $t$ ', is the constant; and $\beta_{k}$ represent the partial slope coefficients of the lagged dependent variable and the set of predictors employed in the current study. denotes the lagged bank margin; Among the predictors, bank-specific variables include, market share $(M S)$, operating costs $(O C)$, managerial efficiency $(M E)$, credit risk $(C R)$, risk aversion $(D R A)$, and the funding costs $(F C)$. Regulatory variables include the capital adequacy ratio $(C A R)$, and the opportunity cost of reserves $(O C R)$, and finally. Two diversification variables $(D I V)$ have been added in the model, i.e., Net Non-Interest Income $(N N I I)$ and Asset Diversity $(A D)$. The model also contains a proxy for market concentration in terms of the Herfindahl-Hirschman Index $(H H I)$ as an industry-specific variable. $\mu_{i}$ denotes the unobservable bank-specific effects, while $\varepsilon_{i t}$ expresses the error term.

\subsubsection{Estimation Approach}

In the present empirical work, Equation (1) is estimated by applying the linear dynamic panel-data regression analysis using the AB GMM estimator. "Arellano and Bond (1991) derived a consistent generalized method of moment estimator for the parameters of the linear dynamic paneldata model". The use of GMM tackles the existence of unobservable bank-specific effects by taking the first-lag of predictors presented in equation (1). The use of GMM estimation also takes care of the probability of endogeneity issues in terms of regressors related to dynamic models. 


\subsection{Empirical Variables and Hypothesis Development}

\subsubsection{Market Share}

In their studies, McShane and Sharpe (1985) and Maudos and De Guevara (2004) have analyzed the relationship of market power with banks' NIM. Banks with a large market share can earn substantial profits, which in return will increase their margins. This study has taken market share to proxy for the market power of a bank following the works of Raharjo, Hakim, Manurung, and Maulana (2014) and Lee and Isa (2017). Raharjo et al. (2014) found an insignificant relationship with NIM, whereas Lee and Isa (2017) found a significant positive relationship between market share with bank margins.

$\mathrm{H}_{1}$ : Market share has a positive relationship with bank margins.

\subsubsection{Operating Cost}

In response to the criticisms on the dealership model, Maudos and De Guevara (2004) incorporated the bank's production function operating costs related to bank services in their extended dealership model. They considered operating cost as a factor that affects net interest margin and it was argued that operating cost needs to be covered even if the market power or risk of any kind is absent. They found that, in the European banking sector, operating cost was affecting bank net interest margins positively.

Several studies have found the operating cost as the most important factor that influences bank margins (AmuakwaMensah \& Marbuah, 2015; Fungáčová \& Poghosyan, 2011; Maudos \& Solís, 2009; Sun, Hassan, Hassan, \& Ramadilli, 2014). Majority of studies concluded that operational cost and bank margins are positively associated (AmuakwaMensah \& Marbuah, 2015; Entrop, Memmel, Ruprecht, \& Wilkens, 2015; Fungáčová \& Poghosyan, 2011; Işik \& Belke, 2017; Lee \& Isa, 2017; Nassar, Martinez, \& Pineda, 2017; Nguyen, 2012; Poghosyan, 2013; Sun et al., 2014; Tarus, Chekol, \& Mutwol, 2012).

$\mathrm{H}_{2}$ : Bank's operating cost has a positive relationship with bank margins.

\subsubsection{Managerial Efficiency}

Managerial efficiency is incorporated in the present study following several previous empirical works on bank margins, with a low value indicating that the bank is efficient, while a high value depicts inefficiency. Studies conducted in European countries suggest that bank net interest margin reduces due to higher efficiency (Claeys \& Vander Vennet, 2008; Vennet, 2002). It was noticed that due to high operational efficiency customers enjoy the benefit of higher rates on their deposits, which reduces bank margins. However, several studies found that when banks are inefficient, the bank margin is also low as these banks function on high-cost liabilities and low profitable assets (Maudos \& De Guevara, 2004; Maudos \& Solís, 2009; Sun, Mohamad, \& Ariff, 2017).

The majority of studies reveal lower bank margins for efficient banks (Ahokpossi, 2013; Angbazo, 1997; Chortareas, Garza-García, \& Girardone, 2012; Dumičić \& Rizdak, 2013; Hijazeen, 2017; Işik \& Belke, 2017; Lee \& Isa, 2017; Maudos \& De Guevara, 2004; Maudos \& Solís, 2009; Sun et al., 2014; Sun et al., 2017; Williams, 2007; Zhou \& Wong, 2008).

$\mathrm{H}_{3}$ : Managerial efficiency is negatively related to the bank margins.

\subsubsection{Credit Risk}

In their study, Angbazo (1997), extended the dealership model by adding credit risk, which is the possibility that the debtor will default. The findings of different studies reveal inconclusive results for the coefficient sign of credit risk. Several studies have found that if credit risk is high, it will lead to higher bank margins (Angbazo, 1997; Demirgüç-Kunt \& Huizinga, 1999; Drakos, 2002; Khawaja \& Ud Din, 2007; Lee \& Isa, 2017; Maudos \& Solís, 2009; Nassar et al., 2017; Poghosyan, 2013; Sun et al., 2017) as well as higher profitability (Dao \& Nguyen, 2020). On the contrary, other studies conducted by Williams (2007) in the Australian context found a negative association of credit risk with bank interest margins. Tran and Nguyen (2020) concluded that stock market capitalization is a signal of financial development in an economy that helps to decline non-performing loans implying that banks can mitigate or reduce their risks in due coarse.

The ratio of Non-Performing Loans (NPLs) to net loans is taken as a proxy for the measurement of credit risk in this research following the studies of Fungáčová and Poghosyan (2011) for Russia who found a negative relationship of credit risk with bank margins for all banks in their sample and Raharjo et al. (2014) in the Indonesian context who found a positive association of credit risk and bank margin contrary to previous empirical works that used the ratio of loan loss provisions to total loans to proxy credit risk. The following hypothesis is postulated to test the relationship:

$\mathrm{H}_{4}$ : There is a positive relationship between credit risk and the bank margin. 


\subsubsection{Degree of Risk Aversion}

It is pertinent to mention that a mandatory capital is kept by all banks to protect banks and depositor's interest by regulatory authorities of the country like the SBP in Pakistan. Banks that are highly capitalized charge lower margins as they face lower borrowing costs and lower risk of bankruptcy, whereas higher capital could be voluntarily raised by banks to signal their solvency or to fulfill regulatory requirements (Ahokpossi, 2013). When compared to depositor's funds, equity capital is costly. It is also a fact that higher equityfinanced banks face lower risk and as a result higher risk aversion. Thus, to cover equity costs, higher risk aversion tends to have a higher bank margin (Maudos \& De Guevara, 2004). Amuakwa-Mensah and Marbuah (2015) suggest that the cost of equity is more expensive than deposits, when the equity-to-total asset ratio is high it reflects bigger risk aversion and predicted to have high margins to cover the equity cost.

Several studies found a positive association of the capitalization ratio with bank margins (Amuakwa-Mensah \& Marbuah, 2015; Angbazo, 1997; Asmar, 2018; Ben Naceur \& Goaied, 2008; Doliente, 2005; Fungáčová \& Poghosyan, 2011; Hijazeen, 2017; Lee \& Isa, 2017; Maudos \& Solís, 2009; Raharjo et al., 2014; Saunders \& Schumacher, 2000; Williams, 2007), whereas Zhou and Wong (2008) and Gunter, Krenn, and Sigmund (2013) found a negative relationship with bank margins. Khawaja and Ud Din (2007), in the Pakistani context, and Işik and Belke (2017) in the Turkish context found the relationship to be insignificant.

$\mathrm{H}_{5}$ : There is a positive association of degree of risk aversion with bank margins.

\subsubsection{Funding Cost}

Funding cost has rarely been studied in the past and this variable could have a significant impact on bank margins. Lee and Isa (2017) examined the funding cost for the first time arguing that deposits are the most important funding source for the bank and banks need to pay a substantial amount as interest or return. In the case of high funding costs, the cost is transferred to the borrower that leads to a higher bank margin. The following hypothesis is formulated as suggested by the study of Lee and Isa (2017):

$\mathrm{H}_{6}$ : There is a positive relationship between funding cost and bank margins.

\subsubsection{Capital Adequacy Ratio (CAR)}

Commercial banks need to maintain a minimum capital as per instructions of the central bank, but banks would still hold the capital even in an unregulated economy because the markets force them to do so (Berger, Herring, \& Szegö, 1995). This capital is kept as a cushion to absorb unforeseen losses to some extent. In situations where these unanticipated losses exceed the cushion amount, the failure of banks takes place. All countries practice the prevalence of regulated capital ratios by commercial banks because bank failures may prove contagious for the economy. Raharjo et al. (2014) found a positive association of CAR with NIM. The following hypothesis is postulated:

$\mathrm{H}_{7}$ : Capital adequacy ratio is significantly predicting bank margin.

\subsubsection{Opportunity Cost of Reserves (OCR)}

All banks have to fulfill reserve regulation that is maintained at the central bank as it reduces the bank's opportunity to provide financing and has a zero return. TRAN and LE (2020) estimated the optimum level of reserves in Vietnam by categorizing the opportunity cost of holding reserves as the cost of reserves, while loss because of a country's default as the benefit of holding reserves and found that optimum reserves in Vietnam are almost higher than the actual reserves during the research period. It is suggested that a higher reserve amount will lead to a higher opportunity cost, and this will allow banks to increase their margins. Several studies hypothesized a positive association of this opportunity cost with bank margins (Angbazo, 1997; Entrop et al., 2015; Lee \& Isa, 2017; Maudos \& Solís, 2009; Zhou \& Wong, 2008).

Several empirical studies found a positive association of the opportunity cost of reserves with bank margin because, with an increase in the volume of reserves, the opportunity cost is increased, so does an interest margin (Maudos \& De Guevara, 2004; Zhou \& Wong, 2008). Several studies also indicate an insignificant relationship between opportunity cost and bank margins (Entrop et al., 2015; Hijazeen, 2017; Işik \& Belke, 2017; Lee \& Isa, 2017; Maudos \& Solís, 2009).

$\mathrm{H}_{8}$ : The opportunity cost of reserves has a positive association with bank margins.

\subsubsection{Bank Diversification}

This study employs two variables to capture diversification for the first time in the Pakistani context, the first is Net Non-Interest Income (NNII) adopted from previous empirical works (Carbo Valverde \& Rodríguez Fernández, 2007; Entrop et al., 2015; Lee \& Isa, 2017; Maudos \& Solís, 2009). The second bank diversification variable employed in the study is asset diversity (Baele, De Jonghe, \& Vander Vennet, 2007; Laeven \& Levine, 2007; Lee \& Isa, 2017; Lin et al., 2012). 
Competition is increasing in the banking industry and due to a decline in profitability banks are shifting towards non-traditional banking activities (Entrop et al., 2015; Mercieca, Schaeck, \& Wolfe, 2007). Nguyen (2012) suggested that sources of income should be diversified by the banks by carrying non-interest activities. In their extended model, Carbo Valverde and Rodríguez Fernández (2007) imply that banks that specialize in loans reduce the cost of financial intermediation by providing fewer margins due to information advantages. Due to non-traditional activities by the banks like non-loan assets and fee income activities, the bank margin increases implying that banks that are diversified have higher margins compared to their specialized counterparts. Numerous empirical studies have found a negative association of a bank's net non-interest income with NIM (Carbo Valverde \& Rodríguez Fernández, 2007; Entrop et al., 2015; Lee \& Isa, 2017; Lepetit, Nys, Rous, \& Tarazi, 2008; Maudos \& Solís, 2009). Lin et al. (2012), in their study, hypothesized and found a positive relationship of NNII with NIM.

$\mathrm{H}_{9 \mathrm{a}}:$ Net non-interest income is negatively related to bank margins.

According to Laeven and Levine (2007), “asset diversity is a measure of diversification across different assets and takes values between 0 and 1 and is increasing in the degree of diversification". Asset diversity is taken as the second diversification variable in the study following the studies of Baele et al. (2007), Laeven and Levine (2007), Lin et al. (2012), and Lee and Isa (2017). Baele et al. (2007), Laeven and Levine (2007), and Lin et al. (2012) found a positive relationship of asset diversity with NIM, whereas, Lee and Isa (2017) found a negative relationship with bank margins. In their empirical studies, Baele et al. (2007) and Laeven and Levine (2007), both concluded that a high value of asset diversity implies that a bank is engaged in a combination of traditional (lending) and nontraditional (non-lending) activities, while a lower value of asset diversity indicates greater bank specialization. The hypothesis for the current study is formulated following the studies Baele et al. (2007), Laeven and Levine (2007), also taken into consideration by Lin et al. (2012) for their hypothesis formulation in their study for Asian countries including Pakistan in their sample.

$\mathrm{H}_{96}$ : There is a positive association of asset diversity with bank margins.

\subsubsection{Market Concentration}

To account for the industry-specific variable in the model, the market concentration is proxied by the HHI of banks, which can also depict the drift in the competition prevailing in the industry following previous studies (Doliente, 2005; Fungáčová \& Poghosyan, 2011; Khawaja \& Ud Din, 2007; Tarus et al., 2012; Trinugroho, Risfandy, \& Ariefianto, 2018; Zhou \& Wong, 2008). There is no consensus in the literature on the direction of the relationship between HHI and bank margins. Khan and Khan (2010), in their empirical work for Pakistani banks, and Trinugroho et al. (2018) in a study for Indonesian rural banks, found a positive association of HHI with NIM, whereas Tarus et al. (2012), in their study, concluded that the relationship is negative; finally, Khawaja and Ud Din (2007) and Fungáčová and Poghosyan (2011) found this relationship to be insignificant in their study. The following hypothesis is formulated for the study:

$\mathrm{H}_{10}$ : There is a significant association of the HerfindahlHirschman index with Bank margins.

\section{Results and Discussion}

\subsection{Multiple Panel Regression Analysis}

The dynamic panel model presented in Equation (1) is empirically analyzed by applying the AB GMM estimator using STATA. For robustness check across diverse econometric estimation techniques, the study also applied pooled Ordinary Least Square (OLS) and Fixed Effects (FE) estimator to compare the results of the current study with previous empirical works. The baseline findings reported in Table 2 for the regression results are estimated using pooled OLS, FE, and GMM estimators. The results and discussion are presented with focusing on the AB GMM estimator only. Arellano and Bond (1991) show that the one-step Sargan test over rejects in the presence of heteroskedasticity, they found a tendency for this test to under reject in the presence of heteroskedasticity. The dynamic panel model estimated in the present study is estimated to correct for heteroskedasticity by selecting robust standard errors.

\subsubsection{Empirical Results from AB GMM Estimator}

The analysis based on testing equation (1) using the $\mathrm{AB}$ GMM estimator with robust standard error to overcome the problem of heteroskedasticity is reported in column 4 of Table 2. The assumption of no autocorrelation in the errors in the levels is tested and the results reveal that the null hypothesis of no autocorrelation of order 2 cannot be rejected, and it is evident that the $\mathrm{AB}$ model assumptions are satisfied and the application of a dynamic panel model is validated by the results. The estimation results reveal that market share has a positive relationship with the bank margins at a $5 \%$ significance level $(\beta=0.106$; $\mathrm{p}$-value $<.05)$ implying that banks with large market share earn substantial profits which 
lead to an increase their margins. The results are in line with the findings of Lee and Isa (2017) for Malaysia.

The banks' operating cost has a positive association with bank margins at a level of significance of 10 percent $(\beta=0.144 ; p$-value $<.10)$. Findings are consistent with the extended dealership model proposed by Maudos and Solís (2009), who incorporated the bank's production function operating costs related to bank services by considering operating cost as a factor for stating the argument that operating cost needs to be covered even if the market power or risk of any kind is absent. The results are consistent with empirical studies that concluded that operational cost and bank margins are positively associated (AmuakwaMensah \& Marbuah, 2015; Entrop et al., 2015; Fungáčová \& Poghosyan, 2011; Işik \& Belke, 2017; Lee \& Isa, 2017; Nguyen, 2012; Poghosyan, 2013; Sun et al., 2014; Tarus et al., 2012).

The managerial efficiency is predicting bank margins negatively during the sample period at a 1 percent significance level $(\beta=-0.021 ; p$-value $<.01)$. The results of this empirical

Table 2: Estimation Results

\begin{tabular}{|c|c|c|c|}
\hline Independent Variables & Pooled OLS (2) & FE (3) & GMM (4) \\
\hline & - & - & $0.081(1.12)$ \\
\hline \multicolumn{4}{|l|}{ Bank-specific variables } \\
\hline MS & $0.077^{* * *}(7.42)$ & $0.156^{* *}(2.18)$ & $0.106^{* *}(2.07)$ \\
\hline OC & $0.267^{* * *}(5.75)$ & $0.122^{* *}(2.08)$ & $0.144^{*}(1.81)$ \\
\hline ME & $-0.016^{* * *}(-18.24)$ & $-0.013^{* * *}(-7.08)$ & $-0.021^{* * *}(-2.95)$ \\
\hline CR & $-0.003(-0.61)$ & $-0.019^{* *}(-2.11)$ & $-0.022^{* * *}(-3.46)$ \\
\hline DRA & $0.013^{* *}(2.22)$ & $0.026^{* *}(2.27)$ & $0.025(1.59)$ \\
\hline FC & $0.273^{* * *}(-21.01)$ & $0.251^{* * *}(9.47)$ & $0.253^{\star * *}(9.46)$ \\
\hline \multicolumn{4}{|l|}{ Regulatory variables } \\
\hline CAR & $-0.001(-0.20)$ & $-0.008(-1.35)$ & $-0.009^{*}(-1.69)$ \\
\hline OCR & $0.007(0.65)$ & $0.007(0.44)$ & $0.003(0.37)$ \\
\hline \multicolumn{4}{|l|}{ Diversification variables } \\
\hline NNII & $-0.180^{* * *}(-3.98)$ & $-0.089^{* *}(-2.08)$ & $-0.069^{*}(-1.72)$ \\
\hline$A D$ & $0.007^{* *}(2.44)$ & $0.017^{* * *}(4.79)$ & $0.012^{\star * *}(2.41)$ \\
\hline \multicolumn{4}{|l|}{ Industry-specific variable } \\
\hline $\mathrm{HHI}$ & $0.008^{* * *}(4.94)$ & $0.007^{* *}(2.66)$ & $0.009^{* * *}(3.98)$ \\
\hline Constant & -0.004 & -0.006 & 0.000 \\
\hline Number of panel-data observations & 288 & 288 & 240 \\
\hline R-square & 0.784 & & \\
\hline R-square within & & 0.754 & \\
\hline Hausman test (FE vs. RE) & & $71.88^{* * *}$ & \\
\hline Wald Chi-square & & & $249.02^{* * *}$ \\
\hline AR 1 (p-value) & & & {$[0.051]$} \\
\hline AR 2 ( $p$-value) & & & {$[0.730]$} \\
\hline Number of Instruments & & & 67 \\
\hline
\end{tabular}

Note: BM is the dependent variable; is the lagged dependent variable; Arellano-Bond suggests the second lags of the dependent variable and all the feasible lags thereafter, for this study with 12 time periods 67 instruments are calculated (55 GMM-type instruments for the dependent variable, 12 standard instruments are given by the first difference of the predictors and the constant); Arellano-Bond order 1 (2) test for first (second) order serial correlation ( $H_{0}$ : no autocorrelation); ${ }^{* * *} p<0.01$, ${ }^{* *} p<0.05,{ }^{*} p<0.1$; $t$-statistics of pooled OLS and FE estimators while Z-statistics of GMM model are reported in parentheses. 
research are in line with previous studies that efficient banks have lower bank margins (Ahokpossi, 2013; Angbazo, 1997; Chortareas et al., 2012; Claeys \& Vander Vennet, 2008; Dumičić \& Rizdak, 2013; Hijazeen, 2017; Işik \& Belke, 2017; Lee \& Isa, 2017; Maudos \& Solís, 2009; Sun et al., 2014; Sun et al., 2017; Williams, 2007; Zhou \& Wong, 2008). Credit risk is significant at a 1 -percent level of significance ( $\beta=-0.022 ; p$-value $<.01)$ having a negative relationship with bank margin, which differs with the majority of results in the empirical literature for bank margins. This might be because the ratio of non-performing loans to total loans is taken as a proxy of credit risk in the study following Fungáčová and Poghosyan (2011) and Raharjo et al. (2014) instead of the ratio of loan loss provisions to total loans employed in previous empirical works (Angbazo, 1997; Işik \& Belke, 2017; Lee \& Isa, 2017; Maudos \& Solís, 2009; Sidabalok, 2011; Tarus et al., 2012; Williams, 2007). The negative sign can also be explained by the argument that a non-performing loan is a loan that is in default or close to default which decreases the interest income leading to a decrease in BM. The result is consistent with the work of Williams (2007) in Australia, and Fungáčová and Poghosyan (2011) in the Russian context.

Finally, the results reveal that there is a positive association of funding cost and bank margin and were found to be the strongest predictor in the regression model significant at a 1 percent level of significance $(\beta=0.253$; $p$-value $<.01)$. The findings of this study are found consistent with the results of Lee and Isa (2017), concluding that in case of high funding cost, the cost is transferred to the borrowers, which leads to higher bank margins. Among the bank-specific variables, only the degree of risk aversion is statistically insignificant in the model.

The CAR is significantly predicting bank margins at a 10 percent significance level $(\beta=-0.009 ; p$-value $<.10)$ which implies that holding buffer capitals may lead margins to decline which is evident from the mean CAR value of 18.8 percent that the Pakistani banks are holding excess buffer capitals on average compared to 11.875 percent requirement set by the SBP under the BASEL-III framework.

The diversification variables employed in the study are found significant with BM. There is a negative association of net non-interest income with bank margin in the present research study and findings are consistent with other previous studies which found a negative association of a bank's net non-interest income with BM (Carbo Valverde \& Rodríguez Fernández, 2007; Entrop et al., 2015; Lee \& Isa, 2017; Lin et al., 2012; Maudos \& Solís, 2009). The second diversification variable, asset diversity is positively associated with bank margin and is line with the results of previous empirical works Baele et al. (2007), Laeven and Levine (2007), and Lin et al. (2012).
For measuring market concentration, HHI was used in the model, the results suggest a positive relationship with bank margins which is in line with the results of Khan and Khan (2010) for Pakistan and Trinugroho et al. (2018) in Indonesia.

\section{Conclusions and Recommendations}

Net Interest Margin (NIM) is usually termed to be a key indicator of the bank's level of efficiency in terms of its fundamental role of financial intermediation. The banking sector is considered to have a major portion of the share in the overall financial sector of economies of the world, and the Pakistani banking industry possesses some unique characteristics due to a dual banking system in place since the inception of Meezan Bank Limited since 2002. Given the presence of a strong rivalry among existing banks in the industry and regulatory requirements laid out by the State Bank of Pakistan (SBP), banks are striving to battle for a greater market share to exercise more market power enabling them to earn greater net income.

Therefore, this research work empirically investigates simultaneously the bank-specific, regulatory requirements, diversification, and industry-specific determinants of bank margins for scheduled banks operating in Pakistan by applying the linear dynamic panel-data model using the AB GMM estimator. The results indicate that market share, operating cost, managerial efficiency, credit risk, and funding cost are significant predictors of the bank margin, whereas, the degree of risk aversion is insignificant in the model among the bank-specific variables. The results show that among the regulatory variables, only the capital adequacy ratio is a significant predictor of BM. Among the diversification variables, both net non-interest income and asset diversity are predicting BM significantly. Finally, the industry-specific variable, HHI is statistically significant with BM.

The authors recommend that future studies may be directed towards empirically analyzing the factors affecting margins for the banking sectors still left in the South Asian context, for example, Afghanistan, Nepal, Bhutan, and the Maldives.

\section{References}

Ahokpossi, C. (2013). Determinants of bank interest margins in Sub-Saharan Africa (No. 13-34): International Monetary Fund.

Allen, L. (1988). The determinants of bank interest margins: A note. Journal of Financial and Quantitative Analysis, 23(2), 231235. https://doi.org/10.2307/2330883

Amuakwa-Mensah, F., \& Marbuah, G. (2015). The determinants of net interest margin in the Ghanaian banking industry. Journal 
of African Business, 16(3), 272-288. http://dx.doi.org/10.1080/ 15228916.2015.1069679

Angbazo, L. (1997). Commercial bank net interest margins, default risk, interest-rate risk, and off-balance sheet banking. Journal of Banking \& Finance, 21(1), 55-87. https://doi.org/10.1016/ S0378-4266(96)00025-8

Arellano, M., \& Bond, S. (1991). Some tests of specification for panel data: Monte Carlo evidence and an application to employment equations. The review of economic studies, 58(2), 277-297. https://doi.org/10.2307/2297968

Asmar, M. (2018). Effects of bank-specific factors on the net interest margin of working banks in Palestine. Journal of Economics \& Management, 33(3), 5-24. https://doi.org/10.22367/ jem.2018.33.01

Baele, L., De Jonghe, O., \& Vander Vennet, R. (2007). Does the stock market value bank diversification? Journal of Banking \& Finance, 31(7), 1999-2023. https://doi.org/10.1016/j. jbankfin.2006.08.003

Barik, S., \& Raje, N. (2019). Net Interest Margins of Banks in India. The Journal of Applied Economic Research, 13(2), 192207. https://doi.org/10.1177/0973801018812545

Ben Naceur, S., \& Goaied, M. (2008). The determinants of commercial bank interest margin and profitability: Evidence from Tunisia. Frontiers in Finance and Economics, 5(1), 106-130.

Berger, A. N., Herring, R. J., \& Szegö, G. P. (1995). The role of capital in financial institutions. Journal of Banking \& Finance, 19(3-4), 393-430. https://doi.org/10.1016/03784266(95)00002-X

Carbo Valverde, S., \& Rodríguez Fernández, F. (2007). The determinants of bank margins in European banking. Journal of Banking \& Finance, 31(7), 2043-2063. https://doi. org/10.1016/j.jbankfin.2006.06.01

Chortareas, G. E., Garza-García, J. G., \& Girardone, C. (2012). Competition, efficiency and interest rate margins in Latin American banking. International Review of Financial Analysis, 24, 93-103. doi:https://doi.org/10.1016/j.irfa.2012.08.006

Chowdhury, A. M. H., Siddiqua, A., \& Chowdhury, A. S. M. M. H. (2016). Relationship between liquidity risk and net interest margin of conventional banks in Bangladesh. Asian Business Review, 6(3), 175-178. https://doi.org/10.18034/abr.v6i3.43

Claeys, S., \& Vander Vennet, R. (2008). Determinants of bank interest margins in Central and Eastern Europe: A comparison with the West. Economic Systems, 32(2), 197-216. https://doi. org/10.1016/j.ecosys.2007.04.001

Dao, B. T. T., \& Nguyen, D. P. (2020). Determinants of Profitability in Commercial Banks in Vietnam, Malaysia and Thailand. Journal of Asian Finance, Economics and Business, 7(4), 133143. https://doi.org/10.13106/jafeb.2020.vol7.no4.133

Demirgüç-Kunt, A., \& Huizinga, H. (1999). Determinants of commercial bank interest margins and profitability: Some international evidence. The World Bank Economic Review, 13(2), 379-408. https://doi.org/10.1093/wber/13.2.379
Doliente, J. S. (2005). Determinants of bank net interest margins in Southeast Asia. Applied Financial Economics Letters, 1(1), 53 57. http://dx.doi.org/10.1080/1744654042000303629

Drakos, K. (2002). The Dealership model for interest margins: The case of the Greek banking industry. Journal of Emerging Market Finance, 1(1), 75-98. https://doi. org/10.1177/097265270200100105

Dumičić, M., \& Rizdak, T. (2013). Determinants of banks' net interest margins in Central and Eastern Europe. Financial Theory and Practice, 37(1), 1-30. https://doi.org/10.3326/ fintp.37.1.1

Entrop, O., Memmel, C., Ruprecht, B., \& Wilkens, M. (2015). Determinants of bank interest margins: Impact of maturity transformation. Journal of Banking \& Finance, 54, 1-19. https://doi.org/10.1016/j.jbankfin.2014.12.001

Fungáčová, Z., \& Poghosyan, T. (2011). Determinants of bank interest margins in Russia: Does bank ownership matter? Economic Systems, 35(4), 481-495. https://doi.org/10.1016/j. ecosys.2010.11.007

Ghasemi, A., \& Rostami, M. (2015). Determinants of interest rate spread in banking industry. International Journal of Applied Research, 1(9), 338-346.

Gunter, U., Krenn, G., \& Sigmund, M. (2013). Macroeconomic, market and bank-specific determinants of the net interest margin in Austria. Retrieved from https://papers.ssrn.com/sol3/ papers.cfm?abstract_id $=2293794$

Hijazeen, I. (2017). The Determinants of Net Interest Margins in the Jordanian Commercial Banks. International Journal of Business and Social Science, 8(8), 27-37.

Ho, T. S., \& Saunders, A. (1981). The determinants of bank interest margins: theory and empirical evidence. Journal of Financial and Quantitative Analysis, 16(4), 581-600. https:// doi.org/10.2307/2330377

Ho, T. S., \& Stoll, H. R. (1983). The dynamics of dealer markets under competition. The Journal of Finance, 38(4), 1053-1074. https://doi.org/10.1111/j.1540-6261.1983.tb02282.x

Husain, I. (2006). Pakistan banking sector. Retrieved from http:// ishrathusain. iba. edu. pk/speeches/WordDocs/Pakistan Banking_Sector. doc

Hussain, I. (2014). Banking industry concentration and net interest margins (NIMs) in Pakistan. Journal of Business Economics and Management, 15(2), 384-402. https://doi.org/10.3846/161 11699.2012.732105

Işik, Ö., \& Belke, M. (2017). An Empirical Analysis of the Determinants of Net Interest Margins of Turkish Listed Banks: Panel Data Evidence from Post-Crisis Era. Sosyoekonomi, 25(34), 227-245. https://doi.org/10.17233/ sosyoekonomi.322057

Islam, M. S., \& Nishiyama, S.-I. (2016). The determinants of bank net interest margins: A panel evidence from South Asian countries. Research in International Business and Finance, 37, 501-514. http://dx.doi.org/doi:10.1016/j.ribaf.2016.01.024 
Kabir, M. N., Worthington, A., \& Gupta, R. (2015). Comparative credit risk in Islamic and conventional bank. Pacific-Basin Finance Journal, 34, 327-353. https://doi.org/10.1016/j. pacfin.2015.06.001

Kannan, R., Narain, A., \& Ghosh, S. (2001). Determinants of net interest margin under regulatory requirements: an econometric study. Economic and Political Weekly, 36(4), 337-344.

Khan, M., \& Jalil, A. (2020). Determinants of Interest Margin in Pakistan: A Panel Data Analysis. Economies, 8(2), 25. https:// doi.org/10.3390/economies8020025

Khan, M. U. H., \& Khan, B. (2010). What drives interest rate spreads of commercial banks in Pakistan? Empirical evidence based on panel data. SBP Research Bulletin, 6, 15-36.

Khawaja, M. I., \& Ud Din, M. (2007). Determinants of interest spread in Pakistan. The Pakistan Development Review, 46(2), 129-143.

Kumari, S. S. M. (2014). Determinants of Interest Margins of Banks in Sri Lanka. South Asia Economic Journal, 15(2), 265280. https://doi.org/10.1177/1391561414548952

Laeven, L., \& Levine, R. (2007). Is there a diversification discount in financial conglomerates? Journal of Financial Economics, 85(2), 331-367. https://doi.org/10.1016/j.jfineco.2005.06.001

Lee, S. P., \& Isa, M. (2017). Determinants of bank margins in a dual banking system. Managerial Finance, 43(6), 630-645. https:// doi.org/10.1108/MF-07-2016-0189

Lepetit, L., Nys, E., Rous, P., \& Tarazi, A. (2008). The expansion of services in European banking: Implications for loan pricing and interest margins. Journal of Banking \& Finance, 32(11), 23252335. https://doi.org/10.1016/j.jbankfin.2007.09.025

Lin, J.-R., Chung, H., Hsieh, M.-H., \& Wu, S. (2012). The determinants of interest margins and their effect on bank diversification: Evidence from Asian banks. Journal of Financial Stability, 8(2), 96-106. https://doi.org/10.1016/j. jfs.2011.08.001

Maudos, J., \& De Guevara, J. F. (2004). Factors explaining the interest margin in the banking sectors of the European Union. Journal of Banking \& Finance, 28(9), 2259-2281. https://doi. org/10.1016/j.jbankfin.2003.09.004

Maudos, J., \& Solís, L. (2009). The determinants of net interest income in the Mexican banking system: An integrated model. Journal of Banking \& Finance, 33(10), 1920-1931. https://doi. org/10.1016/j.jbankfin.2009.04.012

McShane, R., \& Sharpe, I. G. (1985). A time series/cross section analysis of the determinants of Australian trading bank loan/ deposit interest margins: 1962-1981. Journal of Banking \& Finance, 9(1), 115-136. https://doi.org/10.1016/03784266(85)90065-2

Mercieca, S., Schaeck, K., \& Wolfe, S. (2007). Small European banks: Benefits from diversification? Journal of Banking \& Finance, 31(7), 1975-1998. https://doi.org/10.1016/j. jbankfin.2007.01.00
Nassar, K., Martinez, E., \& Pineda, A. (2017). Determinants of banks' net interest margins in Honduras. Journal of Banking and Financial Economics, 1(7), 5-27.

Nguyen, J. (2012). The relationship between net interest margin and noninterest income using a system estimation approach. Journal of Banking \& Finance, 36(9), 2429-2437. https://doi. org/10.1016/j.jbankfin.2012.04.017

Poghosyan, T. (2013). Financial intermediation costs in low income countries: The role of regulatory, institutional, and macroeconomic factors. Economic Systems, 37(1), 92-110. http://dx.doi.org/10.1016/j.ecosys.2012.07.003

Raharjo, P. G., Hakim, D. B., Manurung, A. H., \& Maulana, T. N. (2014). The determinant of commercial banks' interest margin in Indonesia: An analysis of fixed effect panel regression. International Journal of Economics and Financial Issues, 4(2), 295-308.

Saunders, A., \& Schumacher, L. (2000). The determinants of bank interest rate margins: An international study. Journal of International Money and Finance, 19(6), 813-832. https://doi. org/10.1016/S0261-5606(00)00033-4

Sidabalok, L. R. (2011). The determinants of net interest margin in the Indonesian banking sector. SSRN, http://dx.doi. org/10.2139/ssrn. 1917367

Sun, P. H., Hassan, M. K., Hassan, T., \& Ramadilli, S. M. (2014). The assets and liabilities gap management of conventional and Islamic banks in the organization of Islamic cooperation (OIC) countries. Applied Financial Economics, 24(5), 333-346. http:// dx.doi.org/10.1080/09603107.2013.877568

Sun, P. H., Mohamad, S., \& Ariff, M. (2017). Determinants driving bank performance: A comparison of two types of banks in the OIC. Pacific-Basin Finance Journal, 42, 193-203. https://doi. org/10.1016/j.pacfin.2016.02.007

Tarus, D. K., Chekol, Y. B., \& Mutwol, M. (2012). Determinants of net interest margins of commercial banks in Kenya: A panel study. Procedia economics and finance, 2, 199-208. https://doi. org/10.1016/S2212-5671(12)00080-9

Tran, S. H., \& Nguyen, L. T. (2020). Financial Development, Business Cycle and Bank Risk in Southeast Asian Countries. Journal of Asian Finance, Economics and Business, 7(3), 127135. https://doi.org/10.13106/jafeb.2020.vol7.no3.127

Tran, T. V., \& Le, T. P. T. D. (2020). Optimum Reserves in Vietnam Based on the Approach of Cost-Benefit for Holding Reserves and Sovereign Risk. Journal of Asian Finance, Economics and Business, 7(3), 157-165. https://doi.org/10.13106/jafeb.2020. vol7.no3.157

Trinugroho, I., Risfandy, T., \& Ariefianto, M. D. (2018). Competition, diversification, and bank margins: Evidence from Indonesian Islamic rural banks. Borsa Istanbul Review, 18(4), 349-358. https://doi.org/10.1016/j.bir.2018.07.006

Vennet, R. V. (2002). Cost and profit efficiency of financial conglomerates and universal banks in Europe. Journal of Money, Credit and Banking, 254-282. 
Williams, B. (2007). Factors determining net interest margins in Australia: domestic and foreign banks. Financial Markets, Institutions \& Instruments, 16(3), 145-165. https://doi. org/10.1111/j.1468-0416.2007.00122.x
Zhou, K., \& Wong, M. C. (2008). The determinants of net interest margins of commercial banks in mainland China. Emerging Markets Finance and Trade, 44(5), 41-53. https://doi. org/10.2753/REE1540-496X440503 